\title{
INITIAL TREATMENT, SUBLIMATION DRYING AND STORAGE TIME OF SWEET PEPPER CRISPS. MICROBIOLOGICAL QUALITY - PART II
}

\author{
Dorota Sokołowska ${ }^{\mathrm{a}}$, Katarzyna Grotkiewicz ${ }^{\mathrm{b}}$ \\ a Department of Agrobiotechnology, Koszalin University of Technology, Koszalin, Poland, e-mail: \\ dorota.sokolowska91@wp.pl, ORCID 0000-0002-0989-2477 \\ b Department of Production Engineering, Logistics and Applied Informatics, \\ University of Agriculture in Krakow, Krakow, Poland, e-mail: katarzyna.grodkiewicz@urk.edu.pl, \\ ORCID 0000-0001-8564-0928
}

*Corresponding author: e-mail: dorota.sokolowska91@wp.pl

\begin{tabular}{l}
\hline ARTICLE INFO \\
\hline Article history: \\
Received: December 2019 \\
Received in the revised form: \\
January 2020 \\
Accepted: February 2020 \\
\hline Key words: \\
sweet pepper, \\
freeze-drying, \\
quality, \\
processing, \\
crisps, \\
bacteria, \\
fungi
\end{tabular}

\begin{abstract}
The paper presents the impact of the initial processing, cultivar, and storage time on the physical and chemical quality of freeze-dried sweet pepper crisps. Sweet pepper after initial washing and crushing was subjected to further four combinations of the initial processing. The first combination included freezing, the second one blanching in $98^{\circ} \mathrm{C}$ and 2 -minutes time, the third one -dehydration in $2 \%$ solution of ascorbic acid and the fourth one - dehydration in the $2 \%$ solution of sodium chloride. Both types of dehydration were carried out in $70^{\circ} \mathrm{C}$ for 20 minutes with a 1:4 participation of raw material to osmotic solution. Blanched and dehydrated raw materials were subjected to freezing in $-18^{\circ} \mathrm{C}$ for 24 hours. After the completed process of freezing, the samples were moved to a freezer-drier and were dried by sublimation in $-18^{\circ} \mathrm{C}$ and the reduced pressure of $63 \mathrm{~Pa}$. The research that was carried out proved that the microbiological quality of the obtained sweet pepper lyophilizes was significantly affected by the cultivar, treatment type and storage time. These factors significantly diversified the number of microorganisms in sweet pepper crisps. No initial processing before sublimation drying caused a considerably average increase of the number of psychrophile and mesophilic bacteria in crisps from both sweet pepper cultivars. A considerable reduction of their total number took place during blanching and dehydration in the ascorbic acid solution and sodium chloride solution. Additionally, along with the storage time, reduction of the total number of psychrophilic, mesophilic bacteria, fungi and yeasts was reported.
\end{abstract}

\section{Introduction}

The increasing popularity of a diet reach in fruit and vegetables functional food, induces producers to produce a number of innovative and attractive products. Recently, products with a relevant content of fibre and macro and micro-elements are searched for (Janowicz et al., 2012; Kędzierska, 2012; Konopacka and Płochawski, 2003). Crisps made with vegetables 
and fruit are a rich source of those components. They belong to a wide group of "snack food" which constitute dry snacks offered in pubs made by drying, frying, extrusion, flaking, freeze-drying, or baking. They are usually consumed between meals (Janowicz et al., 2012). The subject of fried crisps has been undertaken in Poland for the first time at the end of the 20th century. Apples were dried in rapeseed oil after initial cutting, blanching, dehydration in the water solution from sugar, corn syrup, citric acid and maltodextrin and drying. The ready product had a taste typical for a dry raw material, light colour, and a quite crisp texture (Janowicz et al., 2012). Dried fruit and vegetable crisps are usually produced with sublimation drying (freeze-drying), conventional, vacuum - microwave and mixed (e.g. convective and vacuum-microwave) (Janowicz et al., 2012). Konopacka and Płochawski (2003) developed a technology of production of fruit and vegetable crisps. It was adopted for production of dried apple crisps which during the initial processing were saturated with carbohydrates solutions and colour-fixing components. In order to diversify their taste, addition of vanilla or chocolate aroma was used, and they were dried to a constant final moisture of less than $3 \%$.

Produced in mild conditions of drying, vegetable and fruit products with the name "Crisps" have become a contemporary product on the market. These snacks have properties similar to a fresh raw material including high nutritive values. Adults and children may consume this product. Crisps, amongst others, may be made of potato, kiwi fruit, sweet pepper, pineapple, beetroot, carrot, peach (Janowicz et al., 2012).

The increase in the interest with a healthy and balanced diet and functional food causes that consumers more eagerly reach for no-fat, dried crisps, and fruit and vegetable crisps (Janowicz et al., 2012, Kędzierska, 2012; Konopacka and Płochawski 2003).

Crisps are products with strong hygroscopic properties. Therefore, they must be packed in a hermetic packaging not to cause a considerable reduction of their quality (Konopacka and Płochawski, 2003). Additionally, control of their microbiological conditions is indispensable. Pursuant to the Resolution 178/2002 of the European Parliament and the Council that sets forth general principles for the food law, foodstuff is considered unsafe not only when it is harmful for health but also when it cannot be consumed by people. In this meaning, spoiled food is also dangerous. Food spoilage may start soon after harvesting of raw material (fruit, vegetables) or slaughtering (animal for slaughter, poultry, fish). It is estimated that despite the fact that proper conditions of processing, storage and food distribution of food are ensured, ca. $25 \%$ of their total production is lost as a result of microbiological spoilage. A considerably short shelf life and susceptibility to micro-organisms is a characteristic feature of raw materials and food products. The speed of spoilage processes depends on many factors related directly to composition of food and the type of the contaminating micro-flora (the socalled internal factors) as well as on external factors, i.e. on the time and manner of storage and conditions of distribution. The effect of microbiological decomposition of the elements of food is reduction of their sensory and nutritive value. Microbiological spoilage of food is a multi-stage process where many groups of micro-organisms, adjusted to decomposition of many substrates participate (Libudzisz et al., 2008, Jay et al., 2005).

The aim of the paper was to determine the impact of the initial processing, sweet pepper cultivar, and the storage time on the physico-chemical quality of freeze-dried food. 
Initial treatment...

\section{Material and methods}

The research comprised of two sweet peppers and a white cultivar of Shanghai F1 and Belladonna F1 from Poland. Sweet pepper class 1 quality were purchased in September 2019 on the retail market.

Vegetables were washed, cores were removed, and they were crushed before microbiological analyses were performed. Dried quarters of sweet pepper were cut into thin slices 2-3 mm thick with a multifunctional kitchen robot Siemens type MK 55300 with $110 \mathrm{~W}$ power.

Raw materials before sublimation drying were subjected to initial processing according to 4 following combinations:

- no initial processing,

- blanching in water for 2 minutes in the temperature of $98^{\circ} \mathrm{C}$,

- dehydration (enrichment) in $2 \%$ ascorbic acid solution for 20 minutes in $70^{\circ} \mathrm{C}$,

- dehydration in $2 \%$ sodium chloride solution for 20 minutes in $70^{\circ} \mathrm{C}$.

The sublimation drying process was carried out with lowered pressure of $64 \mathrm{~Pa}$ and the temperature exceeding $-18^{\circ} \mathrm{C}$ in a freeze-drier CT - 60 type.

Figure 1 presents a schematic representation of the laboratory method of obtaining crisps from yellow and white sweet pepper.

Before inoculation was performed for psychrophilic and mesophilic bacteria, a culture medium from agar-agar was made ( $10 \mathrm{~g}$ of agar-agar diluted with $250 \mathrm{ml}$ of distilled water). The obtained medium was sterilized for 15 minutes in $120^{\circ} \mathrm{C}$ with MICROJET sterilizer to prevent from secondary microbiological infection of inoculation. The fragmented sample of fresh sweet pepper or crisps with the weight of $5 \mathrm{~g}$ was diluted with $50 \mathrm{ml}$ of distilled water and homogenized by making thus 1:10 dilution. $1 \mathrm{ml}$ of dilution was placed on two parallel Petri dishes with a sterile end of an automatic pipet pouring $15 \mathrm{ml}$ of a liquid culture medium cooled down to $47^{\circ} \mathrm{C}$. The culture medium on the dish was mixed with a circular movement so that it did not touch the cap. Incubation for psychrophilic bacteria was carried out in $30^{\circ} \mathrm{C}$ for 24 hours and for mesophilic bacteria for 48 hours at $37^{\circ} \mathrm{C}$ in a laboratory incubator ELKON (Błażejak et al., 2010). To determine a number of bacteria, fungi, and yeasts colonies after the incubation period a colony counter was used. Further, a number of colonies per $1 \mathrm{~cm}^{3}$ of dilution was counted by multiplying it by inverse of this dilution.

Before the inoculation was performed for fungi and yeasts, firstly a culture medium from Sabourada agar was made (SS). SS agar was diluted in $250 \mathrm{ml}$ of distilled water and sterilized. Then, with a pipet $1 \mathrm{ml}$ of dilution was collected and poured with $15 \mathrm{ml}$ of SS culture medium. The further procedure was the same as in case of inoculation for bacteria but with a different temperature $\left(25^{\circ} \mathrm{C}\right)$ and incubation time (from ind yeasts included in $1 \mathrm{~cm}$ of solution was determined through multiplication of inverse of this dilution (Błażejak et al., 2010).

Statistical development of research results was carried out with analysis of variance of experiments (ANW) version 2.1. This program was created and developed in DOS system by Stanisław Mańko (the University of Technology and Life Sciences in Bydgoszcz). This analysis enables indication of factors which significantly diversified physico-chemical properties of the obtained product and raw material. In case significant differences were reported, values of the smallest significant differences were provided in tables (NIR at $\alpha=0.05$ ), 
Dorota Sokołowska, Katarzyna Grodkiewicz

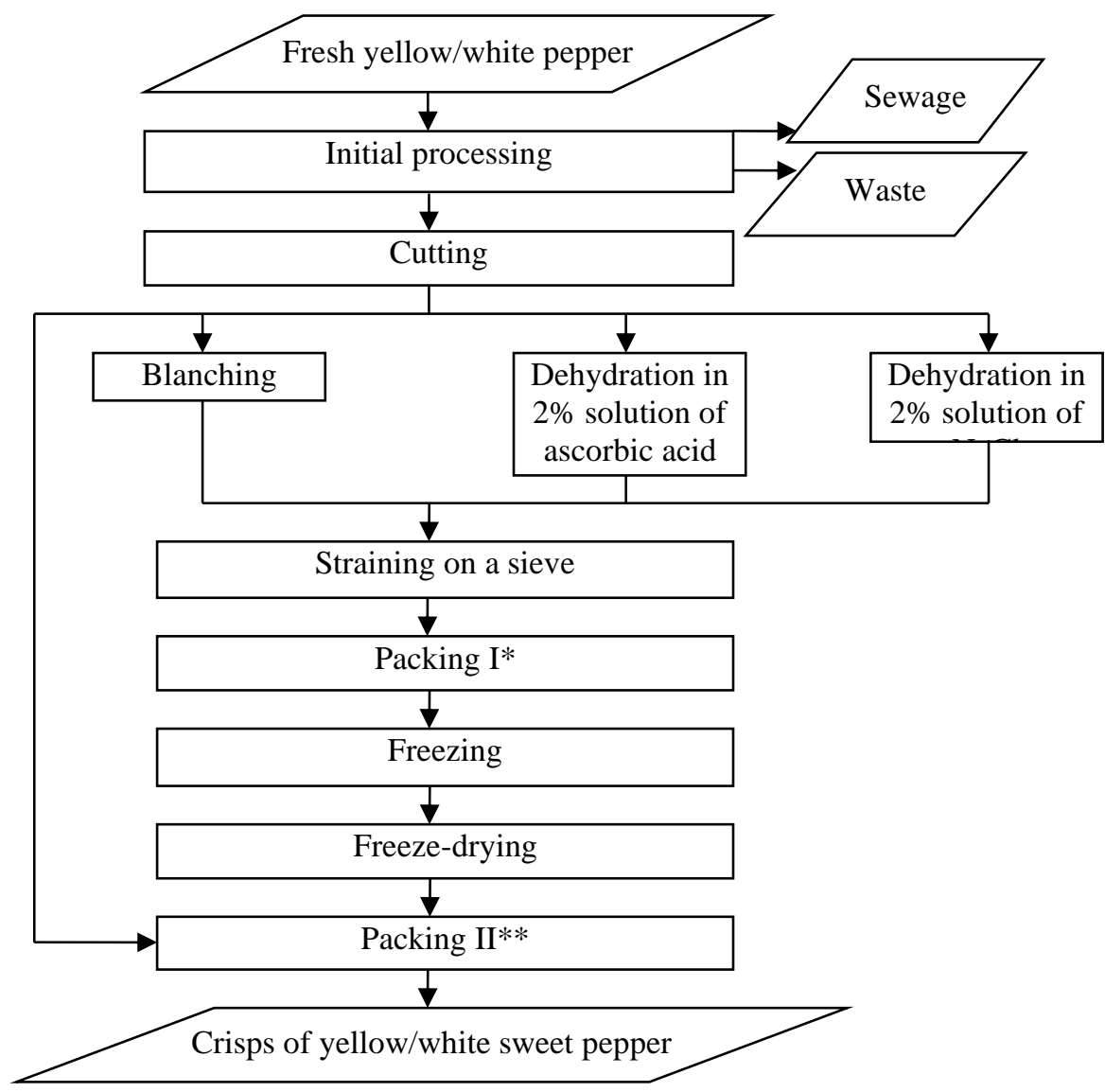

* Packing I in HDPE zip lock bags; ** Packing II in 0.91 glass jars closed with an aluminium twist - off cap

Figure 1. Technological schematic representation of obtaining yellow and white sweet pepper crisps

(Author's own study)

\section{Research results}

\section{Microbiological assessment of raw material}

According to the data presented in table 1 the number of psychrophilic bacteria present in yellow sweet paper Shanghai F1 achieved the level of $4.60 \log \mathrm{CFU} / \mathrm{ml}$, and in white sweet pepper Belladonna $\mathrm{F} 1$ no growth was reported. Meanwhile, the highest number of mesophilic bacteria took place in white sweet pepper and contained $4.70 \mathrm{log} / \mathrm{CFU} \mathrm{ml}$. The number of this type of bacteria in yellow sweet pepper fruit was $3.49 \mathrm{log} / \mathrm{CFU} \mathrm{ml}$. No growth of yeasts and fungi was reported in both analysed cultivars. 
Initial treatment...

Table 1.

The number of micro-organisms in fresh sweet pepper (log CFU/ml)

\begin{tabular}{|c|c|c|c|}
\hline Type of material & $\begin{array}{c}\text { Psychrophilic bacteria } \\
(\log \text { CFU/ml })\end{array}$ & $\begin{array}{c}\text { Mesophilic bacteria } \\
(\log \text { CFU/ml) }\end{array}$ & $\begin{array}{c}\text { Yeasts and fungi (log } \\
\text { CFU/ml) }\end{array}$ \\
\hline $\begin{array}{l}\text { Fresh yellow sweet pepper } \\
\text { Shanghai } \mathrm{F} 1\end{array}$ & 4.60 & 3.49 & No growth \\
\hline $\begin{array}{l}\text { Fresh white sweet pepper } \\
\text { Belladonna F1 }\end{array}$ & No growth & 4.70 & No growth \\
\hline${ }^{* *} \mathrm{NIR}$ (I) cultivar $=1.943$ & & & \\
\hline
\end{tabular}

The type of microbial flora present in fresh vegetables depends mainly on occurrence of soil bacteria, fertilization type, hydration, and purity of water for washing (Ercole et al., 2003; Ahvenainen, 1996). The treatment of washing combined with disinfection removes from 20 to $90 \%$ of micro-organisms from the surface of vegetables (Nguyen-The and Carlin, 1996). The initial processing of raw material including fragmentation and peeling favours microbiological infections. As a result, juice from touched cells constitutes a great medium for numerous micro-organisms. Possibility of their development may reach even $10^{7}-10^{8} \log$ $\mathrm{CFU} / \mathrm{ml}$ (Czapski, 1997). The number of micro-organisms in sweet pepper subjected to analysis was lower and within $10^{2}-10^{3} \log \mathrm{CFU} / \mathrm{ml}$.

The average number of bacteria in fresh white sweet pepper should be within $5.02 \cdot 10^{3}$ $\log \mathrm{CFU} / \mathrm{ml}$. Yeasts and fungi should occur in the amount of $2.41 \cdot 10^{3} \log \mathrm{CFU} / \mathrm{ml}$ (Yogendrarajah et al., 2014). White sweet pepper Belladonna F1 cultivar did not exceed limits of these norms.

With regard to the microbiological quality (purity) analysed cultivars of white and yellow sweet pepper differed significantly (NIR $=1.943)$. It could have been caused by an incorrect initial processing i.e. uncareful washing of vegetables, using microbiologically contaminated water for their washing and by too a high degree of fragmentation of raw materials. Szparaga et al., (2014) when testing fresh plums proved that the contact of raw material with a substrate favours intensification of microbiological contaminations on its surface and a correct initial processing enables their considerable removal (Szparaga et al., 2014). Microbiological contamination of vegetables depends not only on the number of micro-organisms in soil. A method of irrigation and fertilization as well as purity of water of technological lines for washing vegetables also has a significant impact on them (Ercole et al., 2003). Fragmentation of raw material influences a faster development of micro-organisms as a result of destruction of a natural barrier of the skin. A sudden development of micro-organisms is caused by insufficient removal of water and cell juice after cutting and washing raw materials. In technological processes for removal of these water remaining in fruit and vegetables a special type of centrifuges is used (Yilidiz, 1994).

Incorrectly performed activities during sowing on Petri dishes could also have a negative impact on differences in the total number of micro-organisms included in two cultivars of sweet pepper. It could have resulted, inter alia, from a too long time of homogenization, lack of sterility and tightness of closing of vessels in which dilution was performed, short or long period of sedimentation after dilution, the use of contaminated water for dilution, the use of the infected equipment or vessels for inoculation and getting micro-organisms from air. Homogenisation of a sample for dilution should not be longer than 2 minutes. Glass vessels and 
Dorota Sokołowska, Katarzyna Grodkiewicz

Stomacher's bags designed for dilution should be closed. Additionally, a culture medium designed for pouring on dilution on Petri dish after sterilization should be cooled down to $45^{\circ} \mathrm{C}$. The use of a culture medium with a higher temperature kills the microbial flora in a sample (Błażejak et al., 2010).

\section{Microbiological price of a product}

Table 2 presents a number of psychrophilic bacteria in crisps of two sweet pepper cultivars during storage. The average highest number of psychrophilic bacteria occurred in yellow sweet pepper crisps at the level of $5.15 \mathrm{log} C F U / \mathrm{ml}$. With this regard it was higher by $0.55 \log \mathrm{CFU} / \mathrm{ml}$ than the number of these bacteria occurring in fresh raw material. The lowest number of this bacteria type contained crisps enriched with Vitamin C $(0.80 \log \mathrm{CFU} / \mathrm{ml})$. This value reduced in comparison to the basic raw material by $3.80 \log \mathrm{CFU} / \mathrm{ml}$. It was confirmed that osmotic dehydration in ascorbic acid causes reduction of the total number of bacteria (Nowacka and Witrowa-Rajchert, 2011).

Contrary was the case of freeze-dried white sweet pepper. White pepper crisps not subjected to processing included $4.30 \mathrm{log} \mathrm{CFU} / \mathrm{ml}$ of psychrophilic bacteria. While, blanched white pepper crisps had $1.40 \mathrm{log} \mathrm{CFU} / \mathrm{ml}$ of these mirco-organisms. A sudden increase of bacteria was reported in the previously discussed freeze-dried white pepper in comparison to raw material, which did not have those bacteria at all. The storage time influenced the reduction of the number of psychrophilic bacteria.

Table 2 .

The number of psychrophilic bacteria in sweet pepper crisps $(\log C F U / m l)$

\begin{tabular}{|c|c|c|c|}
\hline \multirow{2}{*}{ Material type } & \multicolumn{3}{|c|}{ Storage time (days) } \\
\hline & 30 & 60 & Average \\
\hline Fresh yellow sweet pepper crisps & 5.90 & 1.60 & 3.75 \\
\hline Blanched yellow sweet pepper crisps & 4.90 & 5.40 & 5.15 \\
\hline Yellow sweet pepper crisps +Vit C & 1.60 & No growth & 0.80 \\
\hline Yellow sweet pepper crisps $+\mathrm{NaCl}$ & 3.80 & 1.70 & 2.75 \\
\hline Average & 4.05 & 2.17 & 3.11 \\
\hline Fresh white sweet pepper crisps & 5.90 & No growth & 2.95 \\
\hline Blanched white pepper crisps & 1.20 & 1.60 & 1.40 \\
\hline White sweet pepper crisps +Vit C & 5.60 & 3.00 & 4.30 \\
\hline White sweet pepper crisps $+\mathrm{NaCl}$ & 6.00 & 1.50 & 3.75 \\
\hline Average & 4.67 & 1.52 & 3.10 \\
\hline${ }^{* * *} \mathrm{NIR}(\mathrm{I})_{\text {cultivar }}=0.317$ & \multicolumn{3}{|c|}{${ }^{* * *} \mathrm{NIR}(\mathrm{II})$ processing type $=0.449$} \\
\hline & time & & \\
\hline
\end{tabular}

Yellow sweet pepper crisps were the most microbiologically contaminated by mesophilic bacteria (4.15 $\log \mathrm{CFU} / \mathrm{ml})$. The number of micro-organisms included there was higher by 0.66 (4.15 log CFU/ml) than the basic raw material. The lowest contamination with these micro-organisms was observed in lyophisates from sweet pepper of this cultivar enriched with Vitamin $\mathrm{C}-$ in the amount of $3.10 \log \mathrm{CFU} / \mathrm{ml}$. Their content reduced referred to the control sample by $0.39 \log \mathrm{CFU} / \mathrm{ml}$. 
Initial treatment...

Dried vegetables obtained from fresh white sweet pepper contained the highest number of mesophilic bacteria $(2.80 \log \mathrm{CFU} / \mathrm{ml})$. The lowest number of this bacteria was found in crisps which were soaked in water solutions with sodium chloride before drying $(2.45 \mathrm{log}$ $\mathrm{CFU} / \mathrm{ml}$ ). Both presented values were lower than the number of mesophilic bacteria included in fresh raw material on average by $2.07 \log \mathrm{CFU} / \mathrm{ml}$.

Table 3 .

The number of mesophilic bacteria in sweet pepper crisps (log CFU/ml)

\begin{tabular}{lccc}
\hline \multirow{2}{*}{ Material type } & \multicolumn{3}{c}{ Storage time (days) } \\
\cline { 2 - 4 } Fresh yellow sweet pepper crisps & 30 & 60 & Average \\
Blanched yellow pepper crisps & 6.70 & 1.60 & 4.15 \\
Yellow sweet pepper crisps + Vit C & 3.90 & 2.50 & 3.20 \\
Yellow sweet pepper crisps +NaCl & 2.20 & 4.00 & 3.10 \\
\hline Average & 7.10 & No growth & 3.55 \\
\hline Fresh white sweet pepper crisps & 4.97 & 2.02 & 3.50 \\
Blanched white pepper crisps & 3.40 & 2.20 & 2.80 \\
White pepper crisps +Vit C & 1.60 & 3.50 & 2.55 \\
White pepper crisps +NaCl & 3.30 & 2.20 & 2.75 \\
\hline Average & 3.40 & 1.50 & 2.45 \\
\hline \multicolumn{2}{c}{ NIR (I) cultivar $=0.242$} & 2.92 & 2.64 \\
\hline
\end{tabular}

It was also proved that along with the storage of products, the number of mesophilic bacteria shows a decreasing trend.

Data concerning a general number of yeasts and fungi were presented in table 4 . In crisps made of blanched yellow sweet pepper, the highest number of yeasts and fungi $(3.30 \mathrm{log}$ $\mathrm{CFU} / \mathrm{ml})$ and the lowest in crisps made of yellow sweet pepper with Vitamin C (2.45 log $\mathrm{CFU} / \mathrm{ml}$ ) was reported.

White sweet pepper crisps enriched with ascorbic acid had the highest number of yeasts and fungi $-3.75 \log \mathrm{CFU} / \mathrm{ml}$. Their lowest number was in case of fresh white sweet pepper crisps $-1.00 \log \mathrm{CFU} / \mathrm{ml}$. In lyophilizates made of blanched sweet pepper with $\mathrm{NaCl}$ additions, no growth of these micro-organisms was reported.

Referred to the lack of a general number of yeasts and fungi in fresh sweet pepper of two cultivars, its sudden growth in the obtained dried vegetables was reported during storage.

Interesting observations were made with regard to the average number of yeasts and fungi during storage. This number along with the extending storage time decreased aiming at the total fading.

Brużewicz and Malicki (2007) during a 2-month storage of red sweet pepper in powder proved that the total number of bacteria included there was at the level of $1.93 \log \mathrm{CFU} / \mathrm{ml}$, and mould and yeasts $1.62 \log \mathrm{CFU} / \mathrm{ml}$. The total number of yeasts in the author's own study on freeze-dried yellow and white pepper was lower than the results obtained by Brużewicz and Malicki (2007). 
Dorota Sokołowska, Katarzyna Grodkiewicz

Table 4

The number of yeasts and fungi in sweet pepper crisps (log CFU/ml)

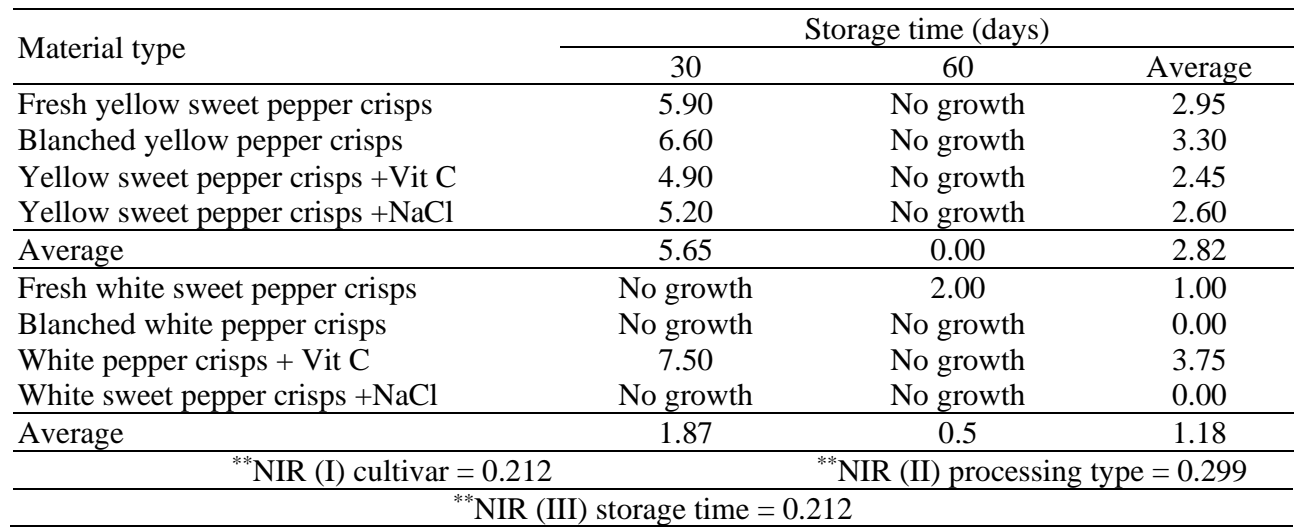

To conclude it should be emphasised that the survivability of micro-organisms is greatly influenced by a chemical composition of freeze-dried food. The more it is rich in various nutrients which act protectively on cells, the higher is their survival rate. Intracellular substances of micro-organisms, that free from damaged or dead cells may be also protective. The survival rate of micro-organisms in preserved food results also from the possibilities of their adaptation to the existing conditions. Moreover, microbial flora which survives the preservation and storage process as a rule shows a high tolerance to a low activity of the environmental water. Reduction of the number of live cells of micro-organisms is the fastest during freezing and in the initial storage period of products. During this time, micro-organisms sensitive to freezing die, only the resistant ones survive. Further dying of micro-organisms, however, considerably slowed down, takes place during storage of preserved products (Majczyna and Białasiewicz, 2001).

\section{Conclusions}

1. Analysis of variance proved that the microbiological quality of the obtained lyophilizates from sweet pepper was caused by a cultivar, type of processing and storage time. These factors significantly diversified the number of micro-organisms in sweet pepper crisps.

2. No initial processing before sublimation drying caused a considerable average increase in the number of psychrophilic and mesophilic bacteria in crisps made of both sweet pepper cultivars referred to raw material. A considerable reduction of their total number took place during blanching and dehydration in the ascorbic acid solution and sodium chloride solution.

3. A two-month storage time significantly influenced the microbiological quality of the obtained sweet pepper crisps. It caused their reduction of the total number of psychrophilic, mesophilic bacteria, fungi, and yeasts. 


\section{References}

Ahvenainen, R. (1996). New approaches in improving the shelf life of minimall processes fruits i vegetables. Trends in Food Sciece and Technology, 7(6), 179-189.

Błażejak, S., Chlebowska-Śmigiel, A., Gientka, I., Gniewosz, M. (2010). Wybrane zagadnienia z mikrobiologii żywności. SGGW, Warszawa.

Brużewicz, S., Malicki A. (2007). Stan mikrobiologiczny wybranych przypraw i przeżywalność w nich drobnoustrojów. Żywność. Nauka. Technologia. Jakość 4(53), 99-108.

Czapski, J. (1997). Warzywa i owoce o matym stopniu przetworzenia. Materiały konferencji Naukowej „Żywność minimalnie przetworzona”, 19-20 czerwca, Kraków, 113-121.

Ercole, C., De Gallo, M., Mosiello, L., Baccella, S. (2003). Escherichia coli detection in vegetable food by potentiometric biosensor. Sensors and Actuators B, 91, 163-168.

Janowicz, M., Kowalska H., Lenart, A. (2012). Przyszłość przekąsek owocowo - warzywnych. Przemyst Fermentacyjny i Owocowo-Warzywny, 2, 9-10.

Jay, J.M., Loessner, M.J., Golden, D.A. (2005). Modern food microbiology. Springer. Switzerland. ISBN 978-0-387-23413-7

Kędzierska, K. (2012). Wpływ temperatury na właściwości sorpcyjne liofilizowanej marchwi. Żywność. Nauka. Technologia. Jakość, 1(38), 55-63.

Konopacka, D., Płochawski, W. (2003). Dietetyczne chrupki z owoców i warzyw - atrakcyjne formy kruchego suszu przeznaczonego do bezpośredniej konsumpcji. Acta Agrophysica, 2(3), 567-577.

Libudzisz, Z., Kowal, K., Żakowska, Z. (2008). Mikrobiologia techniczna. Mikroorganizmy w biotechnologii, ochronie środowiska i produkcji żywności. Tom 2. PWN, Warszawa.

Majczyna, D., Białasiewicz, D. (2001). Przeżywalność drobnoustrojów w niskich temperaturach. Chtodnictwo, 36(5), 45-48.

Nguyen-The, C., Carlin, F. (1996). The microbiology of minimally processed fresh fruits and vegetables. Critical Reviews in Food Science and Nutrion, 36, 371-401.

Nowacka, M., Witrowa-Rajchert, D. (2011). Procesy wstępne stosowane przed suszeniem owoców i warzyw. Przemyst Spożywczy, 6(65), 36-38.

Szparaga, A., Kopeć, A., Czerwińska, E. (2014). Wpływ odwadniania osmotycznego i zamrażalniczego przechowywania na stan mikrobiologiczny śliwek rozmrażanych w komorze próżniowo - parowej. Żywność. Nauka. Technologia. Jakość, 1(92), 137-147.

Yilidiz, F. (1994). Initial preparation, hi ling and distribution of minimally processed refrigerated fruits and vegetables, in Minimally processed refrigerated fruit and vegetables, R.C. Wiley (eds.), Chapman and Hall Inc., New York, 15-65.

Yogendrarajah, P., Deschuyffeleer, N., Jaxsens, L., Sneyers, J.P. (2014). Mycological quality and mycotoxin contamination of Sri Lankan peppers (Pipper nigrum L.) and subsequent exposre assessment. Food Control, 41, 219-230. 
Dorota Sokołowska, Katarzyna Grodkiewicz

\title{
OBRÓBKA WSTĘPNA, SUSZENIE SUBLIMACYJNE I CZASU PRZECHOWYWANIA CRIPSÓW Z PAPRYKI. JAKOŚĆ MIKROBIOLOGICZNA - PART II
}

\begin{abstract}
Streszczenie. W pracy przedstawiono wpływ obróbki wstępnej, odmiany i czasu przechowywania na jakość fizykochemiczną liofilizowanych cripsów z papryki. Paprykę po wstępnym umyciu i rozdrobnieniu poddano 4 dalszym kombinacjom obróbki wstępnej. Pierwsza z kombinacji obejmowała zamrażanie, druga blanszowanie $\mathrm{w}$ temperaturze $98^{\circ} \mathrm{C}$ i czasie 2 minut, trzecia odwadnianie w roztworze $2 \%$ kwasu askorbinowego oraz czwarta odwadnianie w $2 \%$ roztworze chlorku sodu. Obydwa rodzaje odwadniania prowadzono $\mathrm{w}$ temperaturze $70^{\circ} \mathrm{C}$ przez 20 minut przy stosunku surowca do roztworu osmotycznego wynoszącego 1:4. Blanszowane i odwodnione surowce poddano zamrażaniu w temperaturze $-18^{\circ} \mathrm{C}$ przez $24 \mathrm{~h}$. Po zakończonym procesie zamrażania próbki przeniesiono do liofilizatora i suszono sublimacyjnie przy temperaturze $-18^{\circ} \mathrm{C}$ i obniżonym ciśnieniu równym $63 \mathrm{~Pa}$. Przeprowadzone badania wykazały, że na jakość mikrobiologiczną otrzymanych liofilizatów z papryki istotnie wpłynęła odmiana, rodzaj obróbki oraz czas przechowywania. Czynniki te istotnie różnicowały liczbę drobnoustrojów $\mathrm{w}$ cripsach $\mathrm{z}$ papryki. Brak obróbki wstępnej przed suszeniem sublimacyjnym spowodował znaczny średni wzrost liczby bakterii psychrofilnych i mezofilnych w cripsach z obu papryk. Znaczne obniżenie ich ogólnej liczby następowało przy blanszowaniu i odwadnianiu w roztworze kwasu askorbinowego i chlorku sodu. Dodatkowo wraz z czasem przechowywania obserwowano obniżenie ogólnej liczby bakterii psychrofilnych, mezofilnych, grzybów i drożdży.
\end{abstract}

Słowa kluczowe: papryka, liofilizacja, jakość, obróbka, chipsy, bakterie, grzyby 